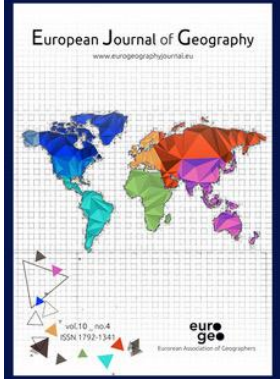

European Journal of Geography

Volume 11, Issue 2, pp. 105 - 122

Article Info:

Received: 03/09/2020; Accepted: 12/12/2020

Corresponding Authors: * kristina.glojek@.uni-lj.si

https://doi.org/10.48088/ejg.k.glo.11.2.105.122

\title{
Hidden black carbon air pollution in hilly rural areas-a case study of Dinaric depression
}

\author{
Kristina GLOJEK' ${ }^{*}$, Asta GREGORIČ ${ }^{2}$, \\ Griša MOČNIK ${ }^{3}$, Andrea CUESTA- \\ MOSQUERA ${ }^{4}$, Alfred WIEDENSOHLER ${ }^{4}$, \\ LUka DRINOVEC ${ }^{3}$, Matej OGRIN ${ }^{1}$
}

${ }^{1}$ University of Ljubljana, Slovenia

${ }^{2}$ Aerosol d.o.o., Ljubljana, Slovenia

${ }^{3}$ Jožef Štefan Institute, Slovenia

${ }^{4}$ Leibniz Institute for Tropospheric Research, Germany

\section{Keywords: \\ hidden geographies, local air pollution, diurnal variation, biomass burning, relief depressions, Loški Potok, Slovenia}

\begin{abstract}
Air pollution is not an exclusively urban problem as wood burning is a widespread practice in rural areas. As we lack information on the air quality situation in rural mountainous regions, our aim is to examine equivalent black carbon $(e B C)$ pollution in a typical rural karst area in the settlement of Loški Potok (Slovenia). eBC mass concentrations were measured by Aethalometer (AE-33) at two sites in Retje karst depression. The rural village station was located at the bottom of the karst depression whereas the rural background station was positioned at the top of the hill. We show the diurnal variation of equivalent black carbon mass concentrations for different seasons. In the populated karst depression, the major source of eBC pollution are households using wood as a heating fuel reaching the highest mass concentrations in winter. Diurnal pattern of eBC from biomass burning and traffic differ due to different source activity and it is influenced by typical formation of a cold air pool from late afternoon until late morning, restricting the dispersion of local emissions. The large difference in mass concentrations between the lowest part of the village (rural station) and the top of the hill (rural background station) indicates that in a vertically stratified and stable atmosphere local sources of black carbon have a major impact on air quality conditions in the area studied. Since in Alpine and Dinaric regions there are many similar inhabited areas, we can expect similar air quality conditions also in other rural hilly areas with limited self-cleaning air capacity.
\end{abstract}

The publication of the European Journal of Geography (EJG) is based on the European Association of Geographers' goal to make European Geography a worldwide reference and standard. Thus, the scope of the EJG is to publish original and innovative papers that will substantially improve, in a theoretical, conceptual or empirical way the quality of research, learning, teaching and applying geography, as well as in promoting

the significance of geography as a discipline. Submissions are encouraged to have a European dimension. The
European Journal of Geography is a peer-reviewed open access journal and is published quarterly.

the significance of geography as a discipline. Submissions are encouraged to have a European dimension. The
European Journal of Geography is a peer-reviewed open access journal and is published quarterly. 


\section{INTRODUCTION}

During incomplete combustion of carbonaceous fuels carbon dioxide, water vapor, carbon monoxide, carbonaceous aerosols, and other volatile organic compounds are released.

Suspended matter has a negative effect on health and causes disturbance of the respiratory system and blood circulation (Mauklen et. al, 2014). Carbonaceous aerosols represent the major fraction of fine particulate matter $\left(\mathrm{PM}_{2.5}\right)$. Light-absorbing carbonaceous aerosols with very large optical absorption across the visible part of the optical spectrum are called black carbon or equivalent black carbon (eBC) if measured optically (Petzold et al., 2013). As a primary pollutant, black carbon is a good indicator of the impact of traffic and residential wood burning on local air pollution. In addition to adverse health effects, airborne particles also influence the climate, as they affect the optical properties of the atmosphere and thus change the Earth's radiation balance. Black carbon strongly absorbs solar radiation and is the most important cause of climate change after carbon dioxide (Bond et al., 2013; Pachauri, 2014); however, unlike carbon dioxide, it is much less persistent and is eliminated from the atmosphere much faster. The link between local sources of black carbon and local air pollution is seen most clearly in areas with a high concentration of local sources and where the selfcleaning capabilities of the atmosphere are also weak. Such areas are, for example, hilly areas, where most settlements are concentrated in valleys, basins or other depressive landforms (e.g. ravines, karst poljes, valleys), and where the level of background pollution is low.

In basins, valleys, and karst depressions, specific meteorological conditions result in a different spatial and temporal pattern of air pollution compared to the wider region or in flat areas (Rakovec and Žabkar, 2012). Cold air pools are formed due to the influence of temperature inversions, and these are particularly persistent in the cold half of the year (Ogrin, 2003). A stable air layer is thus formed near the ground, which strongly impedes or even prevents the exchange of air with the upper parts of the atmosphere and ventilation.

Due to the high concentration of sources, the diversity of spatial uses, the high population density, and the large population in cities and urban areas, it is understandable that the vast majority of global research on air quality, including black carbon pollution, is based in these areas. Furthermore, the great majority of studies were done on traffic-related air pollution. However, due to technological aduancements and legislation, $\mathrm{eBC}$ emissions from traffic are declining, whereas emissions from biomass burning are still largely unregulated in most European countries (Briggs and Long, 2016; Klimont et al., 2017). Over time, interest in research on the impact of biomass burning on air quality has also increased (Herich et al., 2014 and the reference therein). Recent research even shows that the burning of biomass in households for heating is the largest source of particulate concentrations in Slovenia and in many other European regions as well, particularly in rural areas (e. g. Caseiro et al., 2009; Wählin et al., 2010; Herich et al., 2014 and the reference therein; Ogrin et al., 2016; Hovorka et al., 2015; EEA, 2016; Glojek et al., 2019).

Evidently, we do not have enough information on the air quality situation in rural hilly and mountainous areas in Europe. Therefore, the main aim of the study is to examine $\mathrm{EBC}$ pollution in rural mountainous regions where biomass is the predominant 
source of heating fuel. For this purpose, a measurement campaign was conducted in the model region Loški Potok (Slovenia), specifically in the small-size, symmetrically shaped Retje karst depression. Objectives of this paper are (1) to determine the diurnal variability of equivalent black carbon $(e B C)$ pollution in the village Retje (rural station), and at the top of the hill Tabor (rural background station); (2) to compare the $e B C$ pollution levels and diurnal variability during days with temperature inversion and days with normal temperature gradient (mixed atmosphere) for winter; (3) to estimate the contribution of local wood burning to eBC pollution; (4) to compare the observed $e B C$ mass concentrations in the Loški Potok model region with some other European studies; (5) to show the impact of local sources on local air quality level in remote hilly areas; (6) to propose some possible measures to improve the local air quality.

\section{EXPERIMENT}

\subsection{Measurement sites}

The measurements were performed in the Retje depression, Loški Potok ("Loški Potok campaign"), Slovenia. The study area is a typical rural site in the Dinaric Karst region with an elevation of about $700 \mathrm{~m}$ at the bottom of the depression and reaching $900 \mathrm{~m}$ at the top of the surrounding hills. It is a small (approx. $3 \mathrm{~km}$ long and $250-500 \mathrm{~m}$ wide), shallow (approx. $100 \mathrm{~m}$ deep) karst depression (Figure 1) with a nucleated settlement at its bottom and with populated south-facing slopes. The area is surrounded by forest with the nearest industry more than $10 \mathrm{~km}$ distant from the site. With low traffic densities in the wider area (mostly fewer than 100 vehicles per day), households are assumed to be the main local emission source (Glojek et al., 2019). Populated relief depressions with very similar characteristics can be found not only in the Dinaric Karst region but also in other karst, hilly and mountainous areas across Europe and elsewhere.

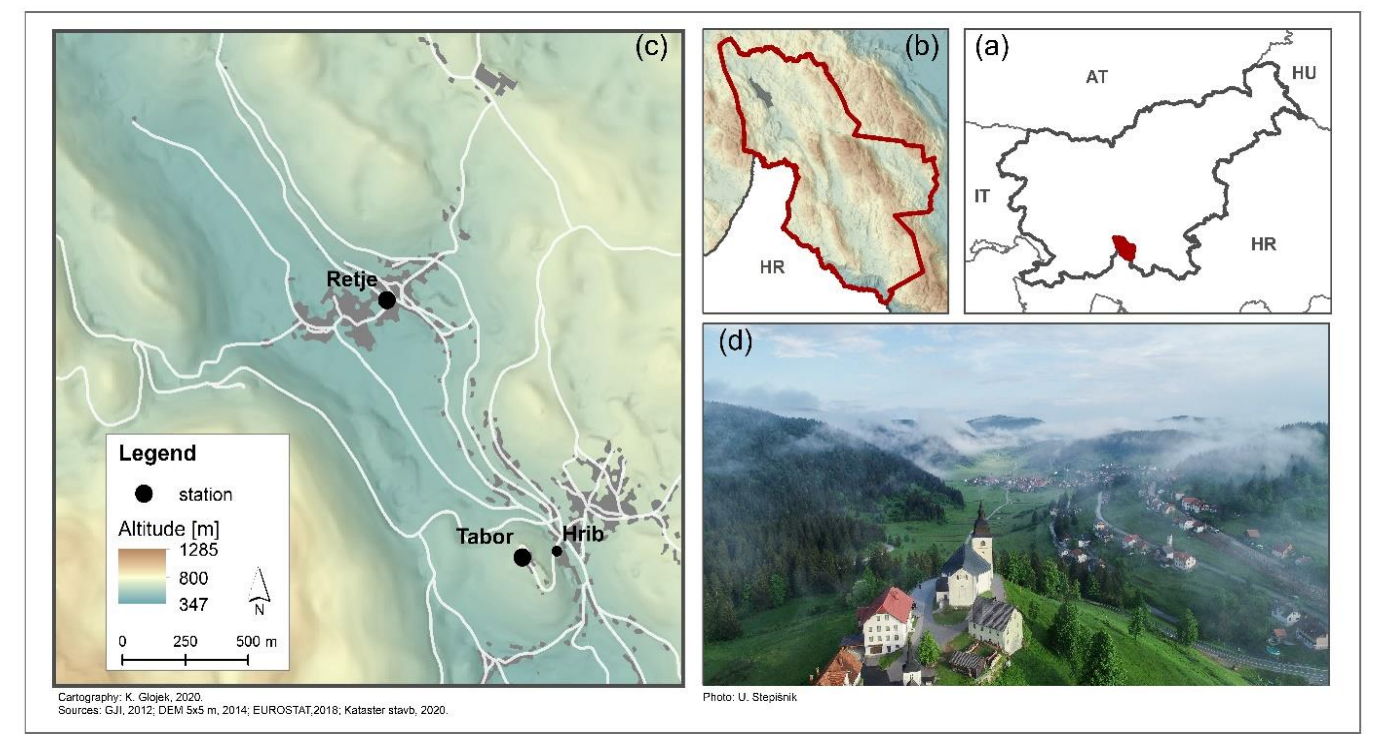

Figure 1. Location of Slovenia with municipality of Loški Potok marked in red (a). Topographic maps of the municipality with marked selected karst depression in grey (b) and of the studied area with two airquality stations (Retje, Tabor) and a meteorological station (Hrib) (c). View of Loški Potok from the air

(d). 
Two monitoring stations at different elevations were set up in the study area. One was placed at the bottom of the depression in the village of Retje $\left(45^{\circ} 42^{\prime} 34.8^{\prime \prime} \mathrm{N}\right.$ $14^{\circ} 34^{\prime} 53.8^{\prime \prime} \mathrm{E}$, el. $715 \mathrm{~m}$ a.s.l.) as a rural village station, and one on top of Tabor Hill ( $45^{\circ} 42^{\prime} 01.5^{\prime \prime} \mathrm{N} 14^{\circ} 35^{\prime} 19.7^{\prime \prime} \mathrm{E}$, el. $815 \mathrm{~m}$ a.s.l.) as a rural background site. In addition to data from these air quality stations, meteorological data were also obtained from the weather station of the Society for Weather and Climate Research in the settlement of Hrib (45 42'4" N $14^{\circ} 35^{\prime} 27^{\prime \prime}$ E, el. 775 m a.s.l.).

\subsection{Measurement of equivalent Black Carbon}

At both air quality stations, equivalent black carbon $(e B C)$ mass concentrations were measured with Aethalometers (model AE33, Magee Scientific, Aerosol, d.o.o.) in the period from October 25, 2017, to May 28, 2018. The duration of the measurement allowed the evaluation of the relative contributions of biomass burning and traffic sources to black carbon pollution in different seasons and under different weather conditions.

The Aethalometer model AE33 provides high time-resolution optical measurement of light-absorbing carbonaceous aerosols in the wavelength range of 370-950 nm (Drinovec et al., 2015). It measures light attenuation through a filter on which aerosols are deposited. Black carbon concentrations are calculated at the wavelength $880 \mathrm{~nm}$ in 1-min time intervals. Attenuation is measured relative to the reference measurements of light transmission through the unloaded part of the same filter, where there is no air flow. Attenuation is defined as the logarithm of the ratio of the intensities of light under the unloaded part of the filter tape and the part of the filter with the particleloaded spot. Attenuation is then converted to $e B C$ mass concentrations using the mass absorption cross section $\sigma_{\text {air }}$ of $7.77 \mathrm{~m}^{2} / \mathrm{g}$ and a multiple scattering parameter $\mathrm{C}=1.39$ (manufacturer's information). The filter tape used was TFE-coated glass fiber filters (no. M8060). The inlet cut-off size was $2.5 \mu \mathrm{m}$. Aethalometers at locations performed sampling using identical measurement settings. Further details about the measurements at the stations can be found in Glojek et al. (2019).

\subsection{Determination of the $\mathrm{eBC}$ sources}

Measurements of the particles' light absorption enable the determination of the wavelength- dependent particle absorption coefficient (Moosmüller et al., 2011). The parameter describing the exponential wavelength dependence is the absorption Ångström exponent $(\alpha)$. This wavelength dependence is different for particles from different pollution sources, enabling separation of traffic and biomass burning for domestic heating (Favez et al., 2009; Sandradewi et al., 2008a; Sandradewi et al., 2008b; Saleh et al., 2013; Zotter et al., 2017).

Based on recommendations from the literature (Sandradewi et al., 2008a) and calculation of the common Angström exponent of all emission sources in the study area, for the wavelength interval between 470 and $950 \mathrm{~nm}$, at Tabor and at Retje, $\alpha$ of 1 for traffic and 2 for biomass burning was used. Discrimination of fossil fuel and biomass burning emissions of $\mathrm{eBC}$ was then performed by the two-component model based on the preselected $\alpha$ values for traffic and biomass burning (Sandradewi et al., 2008a). 


\subsection{Meteorological parameters}

As noted in section 2.1., during the study additional meteorological data were obtained from the database of the Society for Weather and Climate Research (Hrib station). Onehour mean data of air temperature $(T)$, air pressure $(p)$ and relative humidity $(R H)$ from the three measurement locations were used for description of mean meteorological conditions in all seasons during the study (autumn, winter and spring) as well as for the selected days with temperature inversions and days with a normal gradient (mixed atmosphere). Data for precipitation, wind speed and direction from the Hrib station were used as well. Average temperature for every season was calculated as a weighted average of temperatures at $7 \mathrm{am}, 2$ pm and 9 pm (CET) (Kämtz, 1860). Other meteorological variables (average air pressure, average relative humidity, average wind speed and direction) were calculated as the average of measured values at $7 \mathrm{am}, 2 \mathrm{pm}$ and $9 \mathrm{pm}$ (CET).

Table 1. Selection of days with temperature inversions, with normal gradient and undefined days in Loški Potok from December 2017 to February 2018

\begin{tabular}{|l|c|c|c|}
\hline & $\begin{array}{c}\text { Days with temperature } \\
\text { inversions }\end{array}$ & $\begin{array}{c}\text { Undefined } \\
\text { days }\end{array}$ & $\begin{array}{c}\text { Days with normal temperature } \\
\text { gradients }\end{array}$ \\
\hline December 2017 & 15 & 7 & 9 \\
\hline January 2018 & 6 & 13 & 11 \\
\hline February 2018 & 5 & 4 & 18 \\
\hline
\end{tabular}

The study also included the influence of winter temperature inversions on air quality. For the analysis of periods with a temperature inversion, we selected days when a temperature inversion occurred both in the morning and in the evening, whereas for periods with a mixed atmosphere, days without a temperature inversion were used, when the atmosphere was mixed throughout the day and the temperature decreased with increasing eleuation. As undefined days were classified the days when the weather changed during the day and when for part of the day the temperature gradient was normal (i.e. the temperature dropped with increasing elevation), or the temperature did not change with elevation (isotherm), while for part of the day there was a temperature inversion (Table 1). The vertical potential temperature gradient was determined based on the temperature at all three stations at different elevations Retje station (el. $715 \mathrm{~m}$ ), Hrib (el. $775 \mathrm{~m}$ ) and Tabor (el. $815 \mathrm{~m}$ ). Days with temperature inversions and days with a normal temperature gradient were compared with respect to mass concentrations of $e B C$.

\section{RESULTS AND DISCUSSION}

\subsection{Meteorological conditions}

Mean meteorological conditions for different seasons during the measurement campaign are shown in Table 2. Meteorological conditions for the selected days with temperature inversion and days with mixed atmosphere in winter (December, January, February) are presented in Table 3. 
Table 2. Mean ( \pm standard deviation) meteorological conditions for different seasons during the measurement campaign from autumn 2017 to spring 2018 at three locations. Ambient temperature (T), relative humidity $(\mathrm{RH})$ and ambient air pressure $(\mathrm{P})$

\begin{tabular}{|c|c|c|c|c|c|c|c|}
\hline \multirow{2}{*}{ Measurement Period } & \multicolumn{2}{|c|}{ RET]E (el. 715 m) } & \multicolumn{3}{c|}{ HRIB (el. 775 m) } & \multicolumn{2}{c|}{ TABOR (el. 815 m) } \\
\cline { 2 - 8 } & $\begin{array}{c}\mathbf{T} \\
{\left[{ }^{\circ} \mathrm{C}\right]}\end{array}$ & $\begin{array}{c}\text { RH } \\
{[\%]}\end{array}$ & $\begin{array}{c}\text { T } \\
{\left[{ }^{\circ} \mathrm{C}\right]}\end{array}$ & $\begin{array}{c}\text { RH } \\
{[\%]}\end{array}$ & $\begin{array}{c}\mathbf{P} \\
{[\mathrm{hPa}]}\end{array}$ & $\begin{array}{c}\mathbf{T} \\
{\left[{ }^{\circ} \mathrm{C}\right]}\end{array}$ & $\begin{array}{c}\text { RH } \\
{[\%]}\end{array}$ \\
\hline $\begin{array}{c}\text { Autumn } \\
\mathbf{2 0 1 7}\end{array}$ & $4.3 \pm 3.4$ & $82 \pm 8$ & $4.4 \pm 3.4$ & $85 \pm 7$ & $1016.5 \pm 6.6$ & $4.3 \pm 3.6$ & $81 \pm 9$ \\
\hline $\begin{array}{c}\text { Winter } \\
\mathbf{2 0 1 7 / 1 8}\end{array}$ & $-0.3 \pm 4.7$ & $84 \pm 6$ & $-0.2 \pm 4.6$ & $88 \pm 5$ & $1016.6 \pm 9.5$ & $-0.3 \pm 4.5$ & $85 \pm 8$ \\
\hline $\begin{array}{c}\text { Spring } \\
\mathbf{2 0 1 8}\end{array}$ & $8.5 \pm 6.2$ & $77 \pm 10$ & $9.1 \pm 6.2$ & $80 \pm 10$ & $1011.0 \pm 6.4$ & $8.0 \pm 6.4$ & $77 \pm 11$ \\
\hline
\end{tabular}

In autumn and in spring ambient mean temperatures were positive, while in winter mean temperatures at all stations were below zero. Mean temperatures in autumn and in winter were similar at all three stations, despite their different elevations. This is due to the more favorable conditions for temperature inversions during the cold season, when solar radiation is weakened. The winter mean temperatures are shown in Table 3 separately for days with temperature inversion and mixed atmosphere. For these days the lowest mean temperature was at the bottom of the depression, at Retje village station $\left(-2.8{ }^{\circ} \mathrm{C}\right)$, and the highest at the top of the hill, at Tabor station $\left(-0.7^{\circ} \mathrm{C}\right)$, which represents an average gradient of $2.1{ }^{\circ} \mathrm{C} / 100 \mathrm{~m}$. In contrast, a normal temperature gradient prevailed in the spring season, with a mean temperature of $8.5^{\circ} \mathrm{C}$ at Retje village station. A mean temperature of $9.1{ }^{\circ} \mathrm{C}$ was observed at Hrib station, located on the slope of the depression, and $8.0{ }^{\circ} \mathrm{C}$ on top of Tabor hill for the same period. The negative (normal) temperature gradient was the strongest during days with a mixed atmosphere. The mean temperature for all these days was the lowest at the station with the highest elevation, Tabor, with a mean temperature of $-1.3{ }^{\circ} \mathrm{C}$. The highest mean temperature $\left(0.2{ }^{\circ} \mathrm{C}\right)$ was at the bottom of the depression, at Retje station. South-east to south winds prevailed in all seasons, with average wind speeds of only about $1 \mathrm{~m} / \mathrm{s}$.

Table 3. Mean ambient temperatures $(T)$ for days with temperature inversions and for days with mixed atmosphere at three locations in winter months (Dec. 2017-Feb.2018)

\begin{tabular}{|c|c|c|c|}
\hline \multirow{3}{*}{ Measurement period } & RETJE (715 $\mathrm{m}$ a.s.l.) & HRIB (775 $\mathrm{m}$ a.s.l.) & TABOR (815 $\mathrm{m}$ a.s.l.) \\
\cline { 2 - 4 } & $\begin{array}{c}\mathbf{T} \\
{\left[^{\circ} \mathrm{C}\right]}\end{array}$ & $\begin{array}{c}\mathbf{T} \\
{\left[{ }^{\circ} \mathrm{C}\right]}\end{array}$ & $\begin{array}{c}\mathbf{T} \\
{\left[{ }^{\circ} \mathrm{C}\right]}\end{array}$ \\
\hline Temp. inversion & $-2.8 \pm 4.8$ & $-2.0 \pm 4.6$ & $-0.7 \pm 4.4$ \\
\hline Mixed atm. & $0.2 \pm 4.5$ & $-0.3 \pm 4.8$ & $-1.3 \pm 4.8$ \\
\hline
\end{tabular}

During winter months, on days with temperature inversions, mean temperatures at Retje village station and at Hrib station were lower compared to days with a mixed atmosphere. At Retje the mean temperature for days with temperature inversions was 3 ${ }^{\circ} \mathrm{C}$ lower than the mean temperature for days with a mixed atmosphere. At Hrib the difference was $1.7^{\circ} \mathrm{C}$. Conversely, the mean temperature for all days with temperature inversions at Tabor station was higher by $0.6{ }^{\circ} \mathrm{C}$ than the mean temperature for days with a mixed atmosphere. 


\subsection{Diurnal variation of eBC during different seasons at Retje station}

The objective of the study was to determine the diurnal variation of mass concentrations of total $\mathrm{eBC}$ and mass concentrations of $\mathrm{eBC}$ separately by source (i.e. from traffic or burning of biomass-heating), at Retje station in autumn, winter and spring.

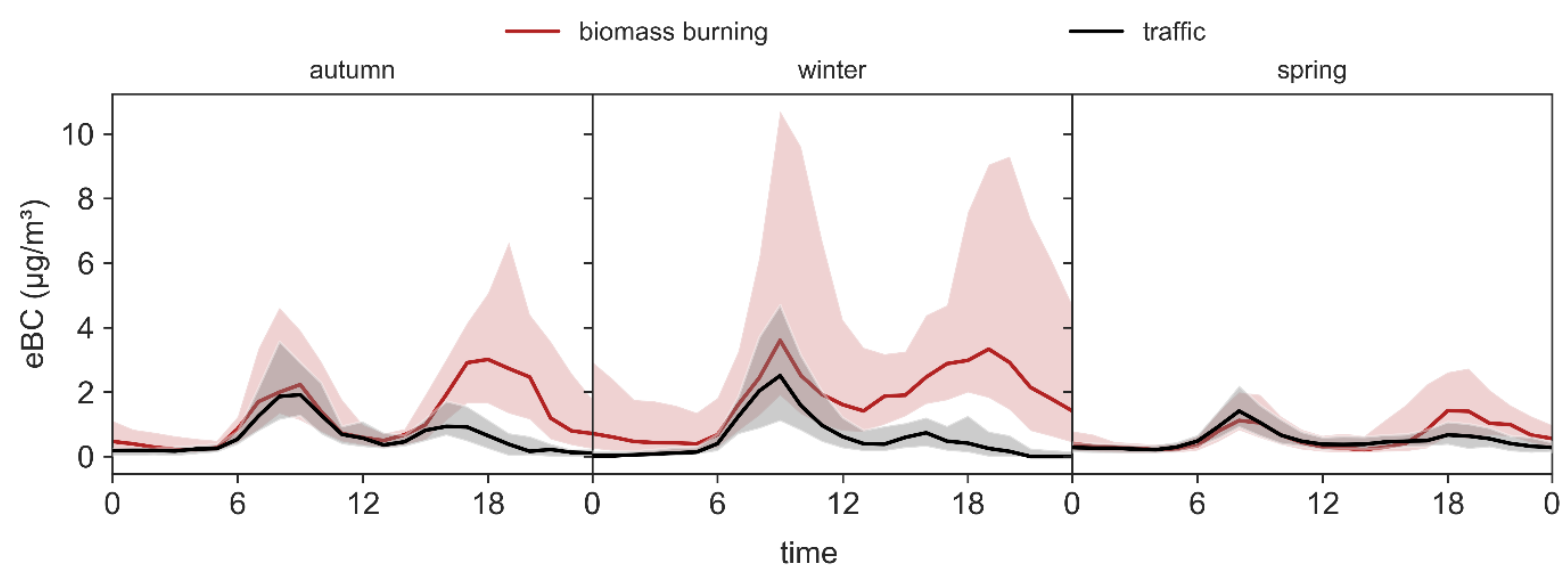

Figure 2. Mean diurnal variation of mass concentrations of $e B C\left(\mu \mathrm{g} / \mathrm{m}^{3}\right)$ shown separately according to source, from traffic or burning of biomass, for different times of year at Retje from autumn 2017 to spring 2018. The lines represent median concentrations and shaded area the variation of the concentrations

(25th to 75th percentile).

Figure 2 and Table 4 show large differences in eBC mass concentrations at Retje during different seasons. Winters are particularly problematic, when the concentration of total $e B C$ in the morning reaches up to $16 \mu \mathrm{g} / \mathrm{m}^{3}$ ( $75^{\text {th }}$ percentile), with a median value of $6.4 \mu \mathrm{g} / \mathrm{m}^{3}$. Concentration due to burning of biomass reaches $10.7 \mu \mathrm{g} / \mathrm{m}^{3}\left(75^{\text {th }}\right.$ percentile), with median of $3.6 \mu \mathrm{g} / \mathrm{m}^{3}$. eBC from traffic peaks in the morning as well, reaching the median value of $2.5 \mu \mathrm{g} / \mathrm{m}^{3}$. During all seasons, the difference between the highest mass concentration due to traffic and to heating is the largest in winter, as the impact of wood burning is the greatest at that time, whereas traffic volume does not significantly change with the season. The relative contribution of biomass burning to $\mathrm{eBC}$ in winter was around 75 to $80 \%$. The primary low is reached between 3 and $4 \mathrm{am}$, when the concentration of total $e B C$ drops to $0.6 \mu \mathrm{g} / \mathrm{m}^{3}$, to which biomass contributes $0.4 \mu \mathrm{g} / \mathrm{m}^{3}$. The primary low is associated with the cessation of sources during the night and the dispersion of $\mathrm{eBC}$. The secondary low, which occurs around $1 \mathrm{pm}$, is due to at least partial decomposition of the inversion layer and reduction of sources, but concentrations remain significantly higher than in the second part of the night.

Also noticeable is the autumn evening peak, when the concentrations of total eBC reach median of $4.3 \mu \mathrm{g} / \mathrm{m}^{3}$, of which heating alone contributes $3 \mu \mathrm{g} / \mathrm{m}^{3}$. While in winter the contribution of each source is very different, in autumn the difference between the contributions of the two sources is much smaller. On average $37 \%$ of $e B C$ was from traffic and 63\% from biomass burning. The morning traffic and heating contributions are almost equal in autumn (around $2 \mu \mathrm{g} / \mathrm{m}^{3}$ ), whereas the evening contributions are still quite different, as there is no afternoon-evening peak for the traffic contribution, yet the evening biomass contribution is akin to both sources together in the morning (Figure 2). This is due to the heating of households in the afternoon and early evening, 
which comprises a larger number of households than morning heating, while at the same time the inversion in Loški Potok is shallower in the afternoon and evening since it is just beginning to form. In autumn the concentration of total $e B C$ is also higher in the morning than in the evening, as the traffic share is much lower in the afternoon. It is also interesting that the diurnal variation of $e B C$ mass concentrations due to traffic is very similar in autumn and winter. The autumn primary low also occurs in the early morning (between 3 and $4 \mathrm{am}$ ), when mass concentrations of total $e B C$ fall to 0.5 $\mu \mathrm{g} / \mathrm{m}^{3}$. At that time the contribution of biomass is the lowest, amounting to $0.2 \mu \mathrm{g} / \mathrm{m}^{3}$. The contribution of traffic is lowest around $11 \mathrm{pm}$, when it reaches only $0.1 \mu \mathrm{g} / \mathrm{m}^{3}$.

Spring mass concentrations are the lowest for both sources, but the decline is much larger for heating, as is to be expected. In spring, there is even lesser need for heating than in autumn, representing $54 \%$ of the total $\mathrm{eBC}$ on average, and the atmosphere is better mixed during the warmer half of the spring season. The measurement period has to be considered for reliable data interpretation. Spring measurements lasted until 28 May, whereas autumn measurements did not begin until 25 October. The lower spring mass concentrations compared to the autumn mass concentrations were therefore also influenced by the fact that the autumn measurements took place only during the colder half of autumn, while the spring measurements also took place in the warmer half of spring. The contribution of biomass burning in the spring in the morning (median of 1.1 $\mu \mathrm{g} / \mathrm{m}^{3}$ ) is very similar to the contribution of traffic (median of $1.4 \mu \mathrm{g} / \mathrm{m}^{3}$ ). In the evening, when the highest mass concentration of $\mathrm{eBC}$ from biomass burning was measured $\left(1.4 \mu \mathrm{g} / \mathrm{m}^{3}\right)$, the median of total $e B C$ was $2.3 \mu \mathrm{g} / \mathrm{m}^{3}$ and did not exceed that of the morning.

Table 4. Maximum and minimum hourly median values of total $e B C$ mass concentrations, contribution of biomass burning $\left(B C_{B B}\right)$ and traffic $\left(B C_{T R}\right)$ expressed in absolute $\left(\mu \mathrm{g} / \mathrm{m}^{3}\right)$ and relative values (\%) during the day from autumn 2017 to spring 2018 at Retje site

\begin{tabular}{|c|c|c|c|c|c|c|c|c|c|c|}
\hline \multirow[t]{2}{*}{ Period } & \multicolumn{2}{|c|}{$\begin{array}{c}e B C \\
{\left[\mu \mathrm{g} / \mathrm{m}^{3}\right]}\end{array}$} & \multicolumn{2}{|c|}{$\begin{array}{c}B C_{B B} \\
{\left[\mu \mathrm{g} / \mathrm{m}^{3}\right]}\end{array}$} & \multicolumn{2}{|c|}{$\begin{array}{c}B C_{B B} / e B C \\
{[\%]}\end{array}$} & \multicolumn{2}{|c|}{$\begin{array}{c}B C_{\mathrm{TR}} \\
{\left[\mu \mathrm{g} / \mathrm{m}^{3}\right]}\end{array}$} & \multicolumn{2}{|c|}{$\begin{array}{c}B C_{T R} / e B C \\
{[\%]}\end{array}$} \\
\hline & MAX & MIN & MAX & MIN & MAX & MIN & MAX & MIN & MAX & MIN \\
\hline $\begin{array}{c}\text { Autumn } \\
2017\end{array}$ & $\begin{array}{c}5.0 \\
(9 \mathrm{am})\end{array}$ & $\begin{array}{c}0.5 \\
(3 \mathrm{am})\end{array}$ & $\begin{array}{c}3.0 \\
(6 \mathrm{pm})\end{array}$ & $\begin{array}{c}0.2 \\
(4 \mathrm{am})\end{array}$ & $\begin{array}{c}86 \\
(11 p m)\end{array}$ & $\begin{array}{c}40 \\
(4 \mathrm{am})\end{array}$ & $\begin{array}{c}1.9 \\
(9 \mathrm{am})\end{array}$ & $\begin{array}{c}0.1 \\
(11 \mathrm{pm})\end{array}$ & $\begin{array}{c}52 \\
(8 \mathrm{am})\end{array}$ & $\begin{array}{c}5 \\
(8 \mathrm{pm})\end{array}$ \\
\hline $\begin{array}{l}\text { Winter } \\
2017 / 18\end{array}$ & $\begin{array}{c}6.4 \\
(9 \mathrm{am})\end{array}$ & $\begin{array}{c}0.6 \\
\text { (3am) }\end{array}$ & $\begin{array}{c}3.6 \\
\text { (9am) }\end{array}$ & $\begin{array}{c}0.4 \\
(5 \mathrm{am})\end{array}$ & $\begin{array}{c}97 \\
(11 \mathrm{pm})\end{array}$ & $\begin{array}{c}50 \\
\text { (6am) }\end{array}$ & $\begin{array}{c}2.5 \\
\text { (9am) }\end{array}$ & $\begin{array}{c}0.0 \\
(10 \mathrm{am})\end{array}$ & $\begin{array}{c}43 \\
\text { (8am) }\end{array}$ & $\begin{array}{c}0 \\
(10 \mathrm{pm})\end{array}$ \\
\hline $\begin{array}{c}\text { Spring } \\
2018\end{array}$ & $\begin{array}{c}2.5 \\
(8 \mathrm{am})\end{array}$ & $\begin{array}{c}0.5 \\
(4 \mathrm{am})\end{array}$ & $\begin{array}{c}1.4 \\
(6 \mathrm{pm})\end{array}$ & $\begin{array}{c}0.2 \\
(4 \mathrm{am})\end{array}$ & $\begin{array}{c}66 \\
(7 \mathrm{pm})\end{array}$ & $\begin{array}{c}37 \\
(2 \mathrm{pm})\end{array}$ & $\begin{array}{c}1.4 \\
(8 \mathrm{am})\end{array}$ & $\begin{array}{c}0.2 \\
(4 \mathrm{am})\end{array}$ & $\begin{array}{c}66 \\
(2 \mathrm{am})\end{array}$ & $\begin{array}{c}24 \\
(9 \mathrm{pm})\end{array}$ \\
\hline
\end{tabular}

The traffic contribution is higher in the morning than in the evening in all seasons. This is due to an afternoon-evening peak, which is more spread out and vehicles operating in the morning (before engines are warmed up), as these pollute the air much more than those with warm engines. Most of the traffic in the morning travels away from Loški Potok and comes back to Loški Potok in the afternoon, when the engines of the vehicles are warmed up, so their emissions are somewhat lower. The spring primary low also occurs early in the morning (around $4 \mathrm{am}$ ), when mass concentrations dropped to only $0.5 \mu \mathrm{g} / \mathrm{m}^{3}$. The biomass and traffic contribution was also the lowest in the early morning with the median values close to $0.2 \mu \mathrm{g} / \mathrm{m}^{3}$. 
Table 5. Arithmetic mean with standard deviation (AM) and median values (MED) of total eBC mass concentrations $(e B C), e B C$ from biomass burning $\left(\mathrm{BC}_{\mathrm{BB}}\right)$ and traffic $\left(\mathrm{BC}_{\mathrm{TR}}\right)$ in absolute $\left(\mu \mathrm{g} / \mathrm{m}^{3}\right)$ and relative values (\%) from autumn 2017 to spring 2018 at Retje site

\begin{tabular}{|c|c|c|c|c|c|c|c|c|c|c|}
\hline \multirow{2}{*}{ Period } & \multicolumn{2}{|c|}{$\begin{array}{c}e B C \\
{\left[\mu \mathrm{g} / \mathrm{m}^{3}\right]}\end{array}$} & \multicolumn{2}{|c|}{$\begin{array}{c}B C_{\mathrm{BB}} \\
{\left[\mu \mathrm{g} / \mathrm{m}^{3}\right]}\end{array}$} & \multicolumn{2}{|c|}{$\begin{array}{c}B C_{\mathrm{BB}} / e B C \\
{[\%]}\end{array}$} & \multicolumn{2}{|c|}{$\begin{array}{c}B C_{\mathrm{TR}} \\
{\left[\mu \mathrm{g} / \mathrm{m}^{3}\right]}\end{array}$} & \multicolumn{2}{|c|}{$\begin{array}{c}B C_{\mathrm{TR}} / e B C \\
{[\%]}\end{array}$} \\
\hline & AM & MED & AM & MED & $A M$ & MED & AM & MED & AM & MED \\
\hline $\begin{array}{c}\text { Autumn } \\
2017\end{array}$ & $3.2 \pm 5.2$ & 1.5 & $1.9 \pm 2.7$ & 0.9 & $63 \pm 26$ & 63 & $1.3 \pm 3.6$ & 0.4 & $37 \pm 26$ & 37 \\
\hline $\begin{array}{l}\text { Winter } \\
2017 / 18\end{array}$ & $5.2 \pm 7.3$ & 2.4 & $4.0 \pm 6.0$ & 1.7 & $75 \pm 23$ & 79 & $1.1 \pm 2.8$ & 0.3 & $25 \pm 23$ & 21 \\
\hline $\begin{array}{l}\text { Spring } \\
2018\end{array}$ & $2.2 \pm 4.3$ & 1 & $1.2 \pm 2.3$ & 0.5 & $54 \pm 26$ & 51 & $1.0 \pm 2.9$ & 0.4 & $46 \pm 26$ & 49 \\
\hline
\end{tabular}

\subsection{Diurnal variation of eBC during different seasons at Tabor}

From Figure 3 it can be seen that the dynamics of $\mathrm{eBC}$ mass concentrations at Tabor are similar to that at Retje, though with significantly lower mass concentrations. Concentrations of total $e B C$ reached just above $3 \mu \mathrm{g} / \mathrm{m}^{3}$ ( $75^{\text {th }}$ percentile) during the winter peaks. The contribution of $\mathrm{eBC}$ due to biomass burning is significantly lower than that at Retje and reaches only $0.9 \mu \mathrm{g} / \mathrm{m}^{3}$, while the traffic contribution reaches 0.6 $\mu \mathrm{g} / \mathrm{m}^{3}$. Relative contribution of biomass burning to total $e B C$ at Tabor site in winter was lower (approx. $63 \%$ of total $e B C$ ) than at Retje (75\% of total eBC on average) (Table 5, Table 7). The winter morning peak exceeds the evening one, and there is no afternoonevening peak for traffic emissions, since they are dispersed faster in the afternoon, while the emissions peak from heating at this time is similar to the morning one. The primary low occurs at around 4 am when mass concentrations drop to $0.5 \mu \mathrm{g} / \mathrm{m}^{3}$.

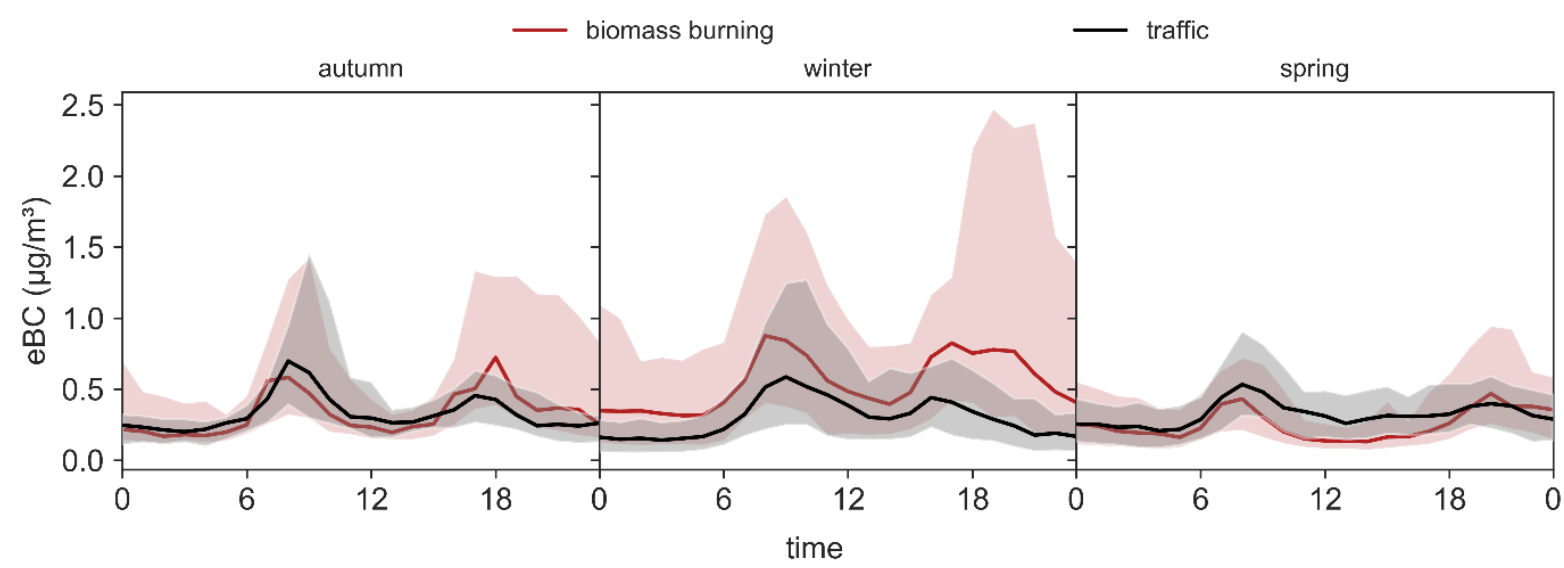

Figure 3. Diurnal variation in mass concentrations of $e B C\left(\mu \mathrm{g} / \mathrm{m}^{3}\right)$ shown separately according to source, from traffic or burning of biomass, for different times of year at Tabor from December 2017 to February 2018. The lines represent median concentrations and shaded area the variation of the concentrations

(25th to 75th percentile).

In autumn, the concentration of $\mathrm{eBC}$ was highest in the morning, when it reached from $0.8 \mu \mathrm{g} / \mathrm{m}^{3}$ ( $25^{\text {th }}$ percentile) to $2.1 \mu \mathrm{g} / \mathrm{m}^{3}$ ( $75^{\text {th }}$ percentile). The traffic and biomass contributions are almost equal (close to $0.6 \mu \mathrm{g} / \mathrm{m}^{3}$ ), while the evening biomass contribution $\left(0.7 \mu \mathrm{g} / \mathrm{m}^{3}\right)$ slightly exceeds the morning contribution and there is no 
significant traffic peak. In autumn as well the primary low occurs between 3 and 4 am, when mass concentrations were only $0.4 \mu \mathrm{g} / \mathrm{m}^{3}$. Average contribution of biomass burning to $e B C$ in autumn was similar at both sites, $55 \%$ at Tabor and $63 \%$ at Retje (Tables 7 and 5).

The spring mass concentrations of $\mathrm{eBC}$ and $\mathrm{eBC}$ due to biomass burning were the lowest at Tabor as well. The share of biomass was $47 \%$ (Table 7 ). The morning mass concentrations of total $e B C$ are close to $1 \mu \mathrm{g} / \mathrm{m}^{3}$, the share contributed by traffic slightly exceeds that of biomass burning (Figure 3). In the evening, the biomass burning contribution is $0.5 \mu \mathrm{g} / \mathrm{m}^{3}$, and there is no traffic peak at this time of day in spring, either. The primary low occurs at around $2 \mathrm{pm}$, when concentrations fall to $0.4 \mu \mathrm{g} / \mathrm{m}^{3}$.

Table 6. Maximum and minimum hourly median values of total $\mathrm{eBC}$ mass concentrations, contribution of biomass burning $\left(B C_{B B}\right)$ and traffic $\left(B C_{T R}\right)$ expressed in absolute $\left(\mu \mathrm{g} / \mathrm{m}^{3}\right)$ and relative values $(\%)$ from autumn 2017 to spring 2018 at Tabor site

\begin{tabular}{|c|c|c|c|c|c|c|c|c|c|c|}
\hline \multirow[t]{2}{*}{ Period } & \multicolumn{2}{|c|}{$\begin{array}{c}e B C \\
{\left[\mu \mathrm{g} / \mathrm{m}^{3}\right]}\end{array}$} & \multicolumn{2}{|c|}{$\begin{array}{c}B C_{B B} \\
{\left[\mu \mathrm{g} / \mathrm{m}^{3}\right]}\end{array}$} & \multicolumn{2}{|c|}{$\begin{array}{c}B C_{B B} / e B C \\
{[\%]}\end{array}$} & \multicolumn{2}{|c|}{$\begin{array}{c}B C_{\mathrm{TR}} \\
{\left[\mu \mathrm{g} / \mathrm{m}^{3}\right]}\end{array}$} & \multicolumn{2}{|c|}{$\begin{array}{c}B C_{T R /} / e B C \\
{[\%]}\end{array}$} \\
\hline & MAX & MIN & MAX & MIN & MAX & MIN & MAX & MIN & MAX & MIN \\
\hline $\begin{array}{c}\text { Autumn } \\
2017\end{array}$ & $\begin{array}{c}1.3 \\
(8 a m)\end{array}$ & $\begin{array}{c}0.4 \\
(3 a m)\end{array}$ & $\begin{array}{c}0.7 \\
(6 \mathrm{pm})\end{array}$ & $\begin{array}{c}0.2 \\
(2 \mathrm{am})\end{array}$ & $\begin{array}{c}64 \\
(6 \mathrm{pm})\end{array}$ & $\begin{array}{c}34 \\
(2 \mathrm{pm})\end{array}$ & $\begin{array}{c}0.7 \\
(8 \mathrm{am})\end{array}$ & $\begin{array}{c}0.2 \\
(3 a m)\end{array}$ & $\begin{array}{c}58 \\
(11 p m)\end{array}$ & $\begin{array}{c}35 \\
(8 \mathrm{pm})\end{array}$ \\
\hline $\begin{array}{l}\text { Winter } \\
2017 / 18\end{array}$ & $\begin{array}{c}1.5 \\
(9 \mathrm{am})\end{array}$ & $\begin{array}{c}0.5 \\
(4 a m)\end{array}$ & $\begin{array}{c}0.9 \\
(8 \mathrm{am})\end{array}$ & $\begin{array}{c}0.3 \\
(4 \mathrm{am})\end{array}$ & $\begin{array}{c}72 \\
(8 \mathrm{pm})\end{array}$ & $\begin{array}{c}51 \\
\text { (midnight) }\end{array}$ & $\begin{array}{c}0.6 \\
(9 \mathrm{am})\end{array}$ & $\begin{array}{c}0.1 \\
(3 a m)\end{array}$ & $\begin{array}{c}45 \\
(11 \mathrm{am})\end{array}$ & $\begin{array}{c}19 \\
(9 \mathrm{pm})\end{array}$ \\
\hline $\begin{array}{c}\text { Spring } \\
2018\end{array}$ & $\begin{array}{c}1.0 \\
(8 \mathrm{am})\end{array}$ & $\begin{array}{c}0.4 \\
(2 \mathrm{pm})\end{array}$ & $\begin{array}{c}0.5 \\
(8 \mathrm{pm})\end{array}$ & $\begin{array}{c}0.1 \\
(2 \mathrm{pm})\end{array}$ & $\begin{array}{c}54 \\
(11 \mathrm{pm})\end{array}$ & $\begin{array}{c}27 \\
\text { (noon) }\end{array}$ & $\begin{array}{c}0.5 \\
(8 \mathrm{am})\end{array}$ & $\begin{array}{c}0.2 \\
(4 \mathrm{am})\end{array}$ & $\begin{array}{c}69 \\
(2 \mathrm{pm})\end{array}$ & $\begin{array}{c}43 \\
(8 \mathrm{pm})\end{array}$ \\
\hline
\end{tabular}

Table 7. Arithmetic mean with standard deviation (AM) and median values (MED) of total $e B C$ mass concentrations $(e B C), e B C$ from biomass burning $\left(B_{B B}\right)$ and traffic $\left(B_{T R}\right)$ in absolute $\left(\mu \mathrm{g} / \mathrm{m}^{3}\right)$ and relative values (\%) from autumn 2017 to spring 2018 at Tabor site

\begin{tabular}{|c|c|c|c|c|c|c|c|c|c|c|}
\hline \multirow{2}{*}{ Period } & \multicolumn{2}{|c|}{$\begin{array}{c}e B C \\
{\left[\mu \mathrm{g} / \mathrm{m}^{3}\right]}\end{array}$} & \multicolumn{2}{c|}{$\begin{array}{c}B C_{\mathrm{BB}} \\
{\left[\mu \mathrm{g} / \mathrm{m}^{3}\right]}\end{array}$} & \multicolumn{2}{c|}{$\begin{array}{c}B C_{\mathrm{BB}} / e B C \\
{[\%]}\end{array}$} & \multicolumn{2}{c|}{$\begin{array}{c}B C_{\mathrm{TR}} \\
{\left[\mu \mathrm{g} / \mathrm{m}^{3}\right]}\end{array}$} & \multicolumn{2}{c|}{$\begin{array}{c}B C_{\mathrm{TR}} / e B C \\
{[\%]}\end{array}$} \\
\cline { 2 - 11 } & $\mathrm{AM}$ & $\mathrm{MED}$ & $\mathrm{AM}$ & $\mathrm{MED}$ & $\mathrm{AM}$ & $\mathrm{MED}$ & $\mathrm{AM}$ & $\mathrm{MED}$ & $\mathrm{AM}$ & $\mathrm{MED}$ \\
\hline $\begin{array}{c}\text { Autumn } \\
2017\end{array}$ & $1.1 \pm 1.5$ & 0.6 & $0.7 \pm 1.1$ & 0.3 & $55 \pm 24$ & 52 & $0.4 \pm 0.6$ & 0.3 & $45 \pm 24$ & 48 \\
\hline $\begin{array}{c}\text { Winter } \\
2017 / 18\end{array}$ & $1.6 \pm 2.3$ & 0.9 & $1.2 \pm 1.8$ & 0.5 & $63 \pm 24$ & 62 & $0.5 \pm 0.8$ & 0.3 & $37 \pm 24$ & 38 \\
\hline $\begin{array}{c}\text { Spring } \\
2018\end{array}$ & $0.9 \pm 1.1$ & 0.6 & $0.5 \pm 0.7$ & 0.2 & $47 \pm 24$ & 45 & $0.4 \pm 0.6$ & 0.3 & $53 \pm 24$ & 55 \\
\hline
\end{tabular}

\subsection{The influence of temperature inversions on air quality in Loški Potok}

Temperature inversions in Loški Potok have a significantly greater impact on the lower part of the depression, in which the village of Retje and part of the village of Hrib are located. As most of the sources of eBC are of local origin, large differences in air quality can occur between the depression and Tabor, which has already been shown by comparison between the seasons, which otherwise include all types of weather. During inversions, the air exchange between the inverted layer and the layer above the inversion practically ceases and the sources below the inversion have very little or no effect on the air quality at Tabor. 
As this is a karst depression, where much of the settlement is concentrated in its lowest part, temperature inversions have a very significant influence due to their frequency. A temperature inversion always occurs in calm and clear weather; in the cold half of the year it occurs in the late afternoon, when the bottom of the depression becomes shaded, and in summer a few hours later. The temperature inversion intensifies overnight and the cold air pool thickens. Due to the sun's radiation, the inversion decays in the early or later morning in the warm half of the year, whereas in winter it can persist for most of the day or even several days. Temperature measurements show that Tabor rises above the inversion layer, except in the case of advection inversion, which is not due to radiative cooling of the depression.

It can be seen in Table 1 that the atmosphere was most mixed in February 2018, when the inversion was present for only five days. The usual temperature gradient indicates good mixing of the atmosphere and an advective type of weather. In February 2018, there were as many as 18 days with this type of weather, and the atmosphere had a normal temperature gradient on 18 days. The most stable atmosphere, however, was in December 2017, when an inversion occurred on 15 days. The differences in the state of the atmosphere were very large, and the differences between Retje and Tabor were also very great.

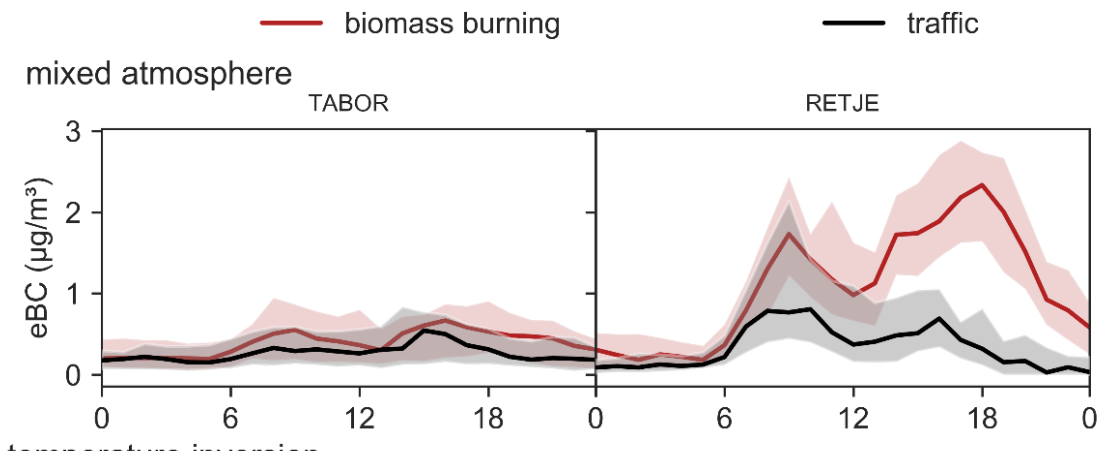

temperature inversion

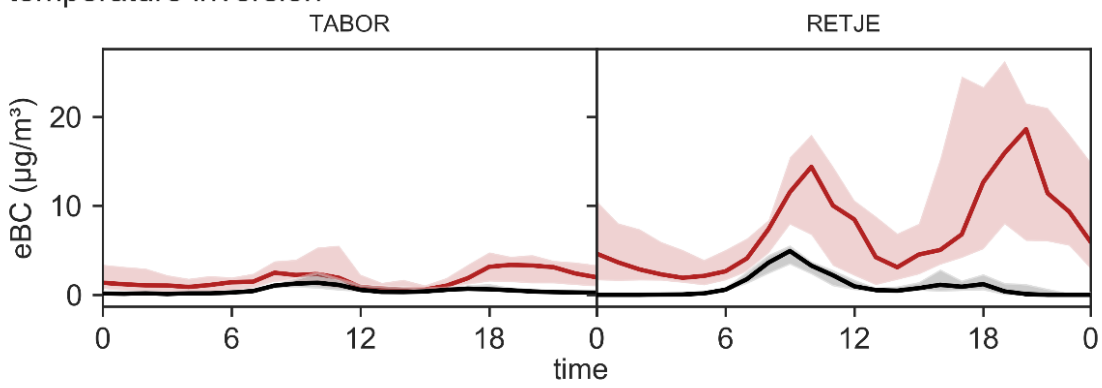

Figure 4. Diurnal variation of mass concentrations of $e B C\left(\mu \mathrm{g} / \mathrm{m}^{3}\right)$ shown separately according to source, from traffic or burning of biomass on days with mixed atmosphere and on days with a temperature inversion at the rural background station Tabor (left side) and at the rural village station Retje (right side) from December 2017 to February 2018. The lines represent median concentrations and shaded area the variation of the concentrations (25th to 75th percentile). Note different $y$-scales for periods with different atmospheric conditions.

On days with temperature inversions, the median mass concentrations of total $e B C$ reached as much as $19.4 \mu \mathrm{g} / \mathrm{m}^{3}$ at Retje during the evening peak (between 7 and $8 \mathrm{pm}$ ), with burning of biomass contributing as much as $18.6 \mu \mathrm{g} / \mathrm{m}^{3}$ (96\% of $e B C$ ). The greatest contribution from traffic was only $4.9 \mu \mathrm{g} / \mathrm{m}^{3}$, at around $9 \mathrm{am}$ (34\% of $e B C$ ). Euen the 
lowest mass concentrations are relatively high during an inversion, reaching $2.4 \mu \mathrm{g} / \mathrm{m}^{3}$ in the primary low, which occurs around $4 \mathrm{am}$.

The situation is completely different when the atmosphere is mixed, as the concentrations of total $e B C$ stay under $3 \mu \mathrm{g} / \mathrm{m}^{3}$, and it is interesting that the peak is reached at $4 \mathrm{pm}$. Euen in cases of mixed atmosphere, the largest part is contributed by biomass burning, which reaches a peak around $6 \mathrm{pm}$, when the median mass concentrations are $2.3 \mu \mathrm{g} / \mathrm{m}^{3}$ (82\% of $\left.e B C\right)$. The lowest median mass concentrations were measured at $5 \mathrm{am}$, at only $0.3 \mu \mathrm{g} / \mathrm{m}^{3}$.

At Tabor mass concentrations of total $\mathrm{eBC}$ were significantly lower than those at Retje. During temperature inversions we measured around $4 \mu \mathrm{g} / \mathrm{m}^{3}$ (at $8 \mathrm{pm}$ ), while on days with a mixed atmosphere the median was only $1.3 \mu \mathrm{g} / \mathrm{m}^{3}$ (at $4 \mathrm{pm}$ ). The highest contribution from traffic at Tabor was only $0.5 \mu \mathrm{g} / \mathrm{m}^{3}$, representing $38 \%$ of $e B C$.

Table 8. Maximum and minimum hourly median values of total mass concentrations of black carbon $(e B C)$ shown separately according to source, traffic (BCtr) or burning of biomass (BCbb), and maximum

and minimum median share of biomass burning $(B C b b)$ in Loški Potok on days with temperature inversions and on days with a mixed atmosphere from December 2017 to February 2018

\begin{tabular}{|c|c|c|c|c|c|c|c|c|c|}
\hline \multirow{2}{*}{ 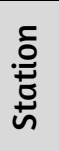 } & \multirow{2}{*}{ Period } & \multicolumn{2}{|c|}{$\begin{array}{c}e B C \\
{\left[\mu \mathrm{g} / \mathrm{m}^{3}\right]}\end{array}$} & \multicolumn{2}{|c|}{$\begin{array}{c}B C_{B B} \\
{\left[\mu \mathrm{g} / \mathrm{m}^{3}\right]}\end{array}$} & \multicolumn{2}{|c|}{$\begin{array}{c}B C_{\mathrm{TR}} \\
{\left[\mu \mathrm{g} / \mathrm{m}^{3}\right]}\end{array}$} & \multicolumn{2}{|c|}{$\begin{array}{c}B C_{B B} / e B C \\
{[\%]}\end{array}$} \\
\hline & & MAX & MIN & MAX & MIN & MAX & MIN & MAX & MIN \\
\hline \multirow{2}{*}{ 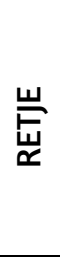 } & $\begin{array}{l}\text { Temperature } \\
\text { inversion }\end{array}$ & $\begin{array}{c}19.4 \\
(8 \\
\mathrm{am})\end{array}$ & $\begin{array}{c}2.4 \\
(4 \\
\mathrm{am})\end{array}$ & $\begin{array}{c}18.6 \\
(8 \\
\mathrm{pm})\end{array}$ & $\begin{array}{c}1.9 \\
(4 \\
a m)\end{array}$ & $\begin{array}{c}4.9 \\
(9 \mathrm{am})\end{array}$ & $\begin{array}{c}0.0 \\
\text { (midnight) }\end{array}$ & $\begin{array}{c}100 \\
(10 \mathrm{pm})\end{array}$ & $\begin{array}{c}61 \\
(7 \mathrm{am})\end{array}$ \\
\hline & $\begin{array}{l}\text { Mixed } \\
\text { atmosphere }\end{array}$ & $\begin{array}{c}2.8 \\
(4 \\
\mathrm{pm})\end{array}$ & $\begin{array}{c}0.3 \\
(5 \mathrm{am})\end{array}$ & $\begin{array}{c}2.3 \\
(6 \\
\mathrm{pm})\end{array}$ & $\begin{array}{c}0.2 \\
(5 \mathrm{am})\end{array}$ & $\begin{array}{c}0.8 \\
(10 \mathrm{am})\end{array}$ & $\begin{array}{c}0.0 \\
(9 \mathrm{pm})\end{array}$ & $\begin{array}{c}88 \\
(6 \mathrm{pm})\end{array}$ & $\begin{array}{c}53 \\
(7 \mathrm{am})\end{array}$ \\
\hline \multirow{2}{*}{ 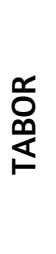 } & $\begin{array}{l}\text { Temperature } \\
\text { inversion }\end{array}$ & $\begin{array}{c}4.0 \\
(8 \\
\mathrm{pm})\end{array}$ & $\begin{array}{c}0.9 \\
(3 \mathrm{pm})\end{array}$ & $\begin{array}{c}3.4 \\
(7 \mathrm{pm})\end{array}$ & $\begin{array}{c}0.6 \\
(2 \mathrm{pm})\end{array}$ & $\begin{array}{c}1.4 \\
(10 \mathrm{am})\end{array}$ & $\begin{array}{c}0.1 \\
(3 \mathrm{am})\end{array}$ & $\begin{array}{c}97 \\
(11 \mathrm{pm})\end{array}$ & $\begin{array}{c}60 \\
\text { (noon) }\end{array}$ \\
\hline & $\begin{array}{l}\text { Mixed } \\
\text { atmosphere }\end{array}$ & $\begin{array}{c}1.3 \\
(4 \\
\mathrm{pm})\end{array}$ & $\begin{array}{c}0.3 \\
(5 \mathrm{am})\end{array}$ & $\begin{array}{c}0.7 \\
(4 \\
\mathrm{pm})\end{array}$ & $\begin{array}{c}0.2 \\
(5 \mathrm{am})\end{array}$ & $\begin{array}{c}0.5 \\
(3 \mathrm{pm})\end{array}$ & $\begin{array}{c}0.1 \\
(5 \mathrm{am})\end{array}$ & $\begin{array}{c}67 \\
(9 \mathrm{am})\end{array}$ & $\begin{array}{c}46 \\
(1 \mathrm{pm})\end{array}$ \\
\hline
\end{tabular}

Where does the source of pollution at Tabor come from? The rectory buildings and residential houses in the immediate vicinity certainly contribute something, and an access road also leads to the church and cemetery there, which makes a small contribution from traffic possible (see Figure 5). As days with inversions, we considered those days when the inversion occurred at least in the morning and in the evening, but could also last throughout the day. During temperature inversions polluted air from the cold air pool does not reach the areas above the pool, so it should not affect the concentrations of black carbon at Tabor. If the upper limit of the inversion is above the height of Tabor, the pollution from the village of Retje could reach Tabor. However, in this case, Tabor would not be warmer than Retje, which was the basic condition for determining the inversion. Such days can therefore be ruled out. If the polluted air at Tabor was due to the decay of the inversion during the day and the transfer of black carbon from the bottom of the depression to Tabor, we would have a peak concentration once in the middle of the day and not in the morning or evening. Thus, the pollution at Tabor during the inversions is also the result of sources in the village of 
Hrib, which lies above the inversion, in addition to the houses and the access road in the immediate vicinity. There are fewer of these sources there; they are more remote and their dispersion is more intense, so their impact is smaller, which explains the much lower concentrations of black carbon at Tabor. This is also confirmed by the diurnal variation of pollution, as we see that the typical daily dynamics of concentrations are maintained.

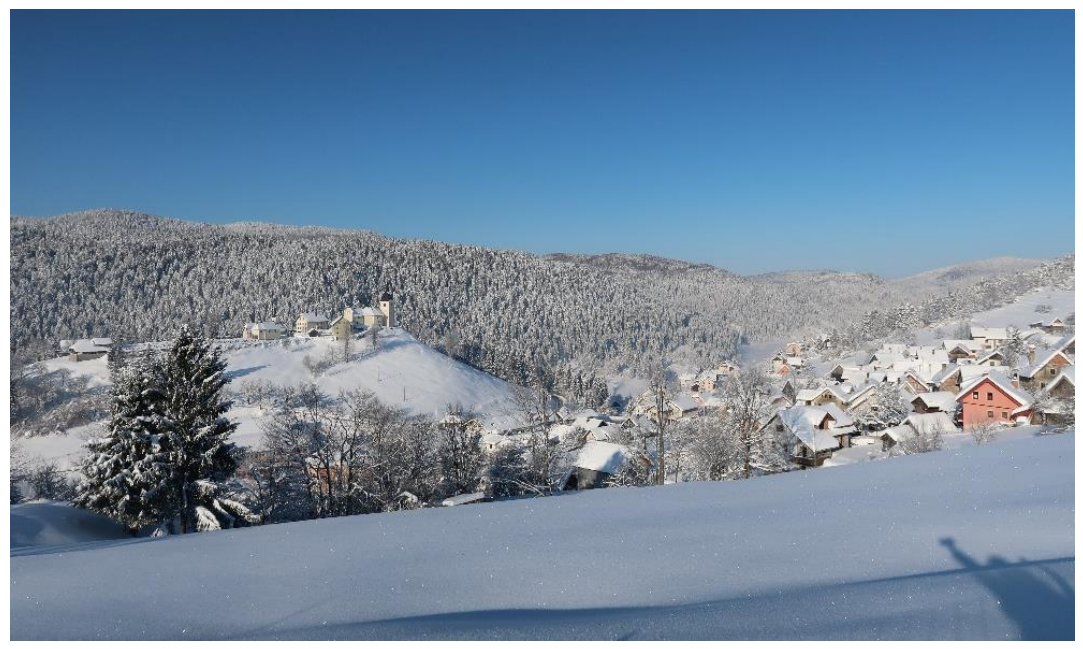

Figure 5. View of hill Tabor with church, rectory buildings and residential houses on the top. An access road from the nearest biggest settlements Hrib (in the photo) and Retje (only partly seen in the photo) leads to the church and cemetery (Photo: Kristina GLOJEK).

Considerably larger differences between pollution levels during an inversion and in a mixed atmosphere are found at Retje, at the bottom of the depression. Concentrations of $e B C$ are very high during the time of an inversion and reach $18 \mu \mathrm{g} / \mathrm{m}^{3}$ in the morning peak, and an even higher peak occurs early in the evening when mass concentrations reach $19.4 \mu \mathrm{g} / \mathrm{m}^{3}$ (median values). The morning peak, which is caused by biomass burning ( $81 \%$ of $e B C)$, reaches its highest point around $10 \mathrm{am}$, occurring an hour later than the traffic peak. The evening peak from biomass burning occurs between $6 \mathrm{pm}$ and $9 \mathrm{pm}$, while the traffic peak in the afternoon or evening is practically nonexistent and the contribution of traffic is around $1 \mu \mathrm{g} / \mathrm{m}^{3}$ (7\% of $\left.e B C\right)$. When the atmosphere is mixed, the dynamics of mass concentrations at Retje are similar, except that the concentrations are much lower. The morning peak is akin to the evening peak, while the traffic peak occurs only in the morning and coincides with the morning peak due to biomass burning. Values at Retje when the atmosphere is mixed reach below $3 \mu \mathrm{g} / \mathrm{m}^{3}$ in the morning and in the evening.

Measurements also clearly showed that the main source of $e B C$ in the villages of Retje and Hrib and on Tabor is of local origin, with biomass burning strongly predominant (60-90\% of $e \mathrm{BC})$. Temperature inversions have a strong negative impact on air quality in the depression and at those times the concentrations are also higher above the inversion, which suggests the contribution of sources that are located above the cold air pool. When the atmosphere is mixed, the situation is much better, but the local contribution can still be seen in Retje, as the wind speed in the depression is poor, and household burning of biomass also takes place in windy weather. 


\section{CONCLUSIONS}

In the study we present the diurnal variability of equivalent black carbon (eBC) mass concentration in karst region Loški Potok (Slovenia), an example of a rural hilly area with relief conductive for cold air pool formation. Measurements of $e B C$ were carried out from autumn 2017 to spring 2018 at the bottom of the relief depression in the village Retje and at the top of the hill Tabor. eBC sources were determined by the so called Aethalometer model (Sandradewi et al., 2008a).

Measurements showed large differences in the level of air pollution, especially between winter and spring. Autumn mass concentrations of $\mathrm{eBC}$ were closer to those of winter than of spring, but autumn measurements took place only in the cold half of the autumn season and thus are not entirely representative. Especially in autumn and winter, the daily variations of $\mathrm{eBC}$ mass concentrations resulting from the burning of biomass are clearly visible, when the primary peak occurs around $10 \mathrm{am}$ and the secondary one around $8 \mathrm{pm}$. The contributions of biomass in the morning and evening are very similar, but there is a crucial difference in the traffic contribution: in the morning, a traffic peak usually occurs about an hour before the biomass peak, but in the late afternoon or evening, no major peak in the traffic contribution to eBC mass concentrations was observed.

On days with a temperature inversion, the concentrations of $\mathrm{eBC}$ at Retje are significantly higher than on days without an inversion. On days with an inversion, the median of $e B C$ in the primary peak at Retje reached $19.4 \mu \mathrm{g} / \mathrm{m}^{3}$, which is comparable to the traffic stations of larger urban centres (e.g. Fuller et al. 2014; Manigrasso et al. 2017; Di lanni, 2018; Küpper et al. 2018), and even on days without an inversion they reach $4 \mu \mathrm{g} / \mathrm{m}^{3}$ in the primary peak. The air at Tabor is much cleaner; it is most polluted during periods of calm weather, when there is an inversion in Retje and the influence of sources located above the inversion layer reaches Tabor. But even then, the concentrations reached only about $4 \mu \mathrm{g} / \mathrm{m}^{3}$. During periods of windy weather, the concentrations at Tabor are lower than $2 \mu \mathrm{g} / \mathrm{m}^{3}$.

The strong impact of inversions on $\mathrm{eBC}$ mass concentrations in Loški Potok confirms the influence of local sources on air quality. To improve quality, emissions need to be reduced at the local level. In particular, the focus should be on measures to reduce emissions from households burning of biomass and less so on traffic-related measures. This means renouating buildings to make them more energy efficient to reduce heating needs, replacing old boilers with newer, more efficient ones, equipping combustion systems with particle filters and also installing heat pumps and constructing district heating systems that most households can be connected to.

This study has shown that even sparsely populated areas far away from densely populated regions are exposed to high concentrations of $e B C$ for part of the year. Areas such as Loški Potok are found in Dinaric environments as well as in the Alps and elsewhere in hilly regions, so similar conditions can be expected wherever biomass predominates as an energy source and where local topography reduces the selfcleaning capacity of these areas. This is a valuable piece of information that can improve our understanding of areas with air pollution problems and factors that contribute to the problems. High time-resolution study can enhance understanding of $e B C$ and wood combustion related health effects in rural areas and in general as well. 
Furthermore, the results can be valuable for managing and planning domestic heating systems in rural areas.

\section{ACKNOWLEDGEMENTS}

This paper presents some results from the "Loški Potok" campaign that was supported financially by the Slovenian Research Agency, COST Action CA16109 and the Municipality of Loški Potok. Research cooperation and support of the Aerosol d.o.o. research group (Irena Ježek, Martin Rigler and Gašper Laurič), TROPOS (Honey Dawn C. Alas, Kay Weinhold, Mike Merkel, Thomas Müller, Dominik van Pinxteren and Hartmut Herrmann) and the Jožef Štefan Institute (Maja Remškar) to this project is gratefully acknowledged. We thank Martina Ristorini for her valuable help with field measurements and other volunteers as well. Finally, we are truly grateful to the local community, who offered their premises for the setting up of measuring stations, for their friendly welcome.

\section{REFERENCES}

Bond, T. C., Doherty, S. J., Fahey, D., W., Forster, P. M., Bernsten, T., DeAngelo, B., J., Flanner, M. G., Ghan, S., Kärcher, B., Koch, D., Kinne, S., Kondo, Y., Quinn, P. K., Sarofim, M. C., Schultz, M. G., Schulz, M., Venkataraman, C., Zhang, H., Zhang, S., Bellouin, N., Guttikunda, S. K., Hopke, P. K., Jacobson, M. Z., Kaiser, J. W., Klimont, Z., Lohmann, U., Schwarz, J. P., Schindell, D., Storelumo, T., Warren, S. G., and Zender, C. S. (2013). Bounding the role of black carbon in the climate system. A scientific assessment. Journal of Geophysical Research: Atmospheres: 118 (11): 53805552.

Briggs, N.L., and Long, C.M. (2016). Critical review of black carbon and elemental carbon source apportionment in Europe and the United States. Atmospheric Environment: 144: 409-427.

Caseiro, A., Bauer, H., Schmidl, C., Casimiro, A. P., and Puxbaum, H. (2009). Wood burning impact on PM 10 in three Austrian regions. Atmospheric Environment: 43: 21486-2195.

Houorka, J., Pokorná, P., Hopke, P. Křůmal, K., Mikuška, P., and Píšouá, M. (2015). Wood combustion, a dominant source of winter aerosol in residential district in proximity to a large automobile factory in Central Europe. Atmospheric Environment: 113: 98-107. Auailable at 10.1016/j.atmosenu.2015.04.068 (Accessed 15 June 2020).

Di Ianni, A., Costabile, F., Barnaba, F., Di Liberto, L., Weinhold, K., Wiedensholer, A., Struckmeier, C., Drewnick F., and Gobbi, G.P. (2018). Black Carbon Aerosol in Rome (Italy): Inference of a Long-Term (2001-2017) Record and Related Trends from AERONET Sun-Photometry Data. Atmosphere 9 (3): 1-24. Auailable at 10.3390/atmos8120249 (Accessed 15 June 2020).

Drinovec, L., Močnik, G., Zotter, P., Préuôt, A. S. H., Ruckstuhl, C., Coz, E., Rupakheti, M., Sciare, J., Müller, T., Wiedensholer, A., and Hansen, A. D. A. (2015). The "dual-spot" Aethalometer: an improved measurement of aerosol black carbon with real-time 
loading compensation. Atmospheric Measurment Techniques: 28 (5): 1965-1979. Available at 10.5194/amt-8-1965-2015 (Accessed 15 June 2020).

EEA Report. (2016). Air quality in Europe - 2016 report. No 28/2016. Copenhagen: European Environmental Agency.

Favez, O., Cachier, H., Sciare, J., Sarda-Estève, R., and Martinon, L. (2009). Euidence for a significant contribution of woodburning aerosols to PM2.5 during the winter season in Paris, France. Atmospheric Environment: 43: 3640-3644.

Fuller, G. W., Tremper, A. H, Baker, T. D., Espen Yitri, K., and Butterfield, D. (2014). Contribution of Wood Burning to PM10 in London. Atmospheric Environment: 87: 87-94. Auailable at 10.5194/amt-8-1965-2015 (Accessed 15 June 2020).

Gjerek, M., Koleša, T., Logar, M., Matauž, L. Murovec, M., Rus, M., and Žabkar, R. (2019). Kakovost zraka v Sloveniji v letu 2018. Letno poročilo, Ljubljana, MOP ARSO. Available at

http://www.arso.gou.si/zrak/kakouost\%20zraka/poro\%C4\%8Dila\%20in\%20publik acije/Letno_Porocilo_2018.pdf (Accessed 15 June 2020).

Glojek, K., Gregorič, A., and Ogrin, M. (2019). Black carbon air pollution - Case Study of Loski Potok. Dela: 50: 25-43.

Helin, A., Niemi J., V., Virkkula, A., Pirjola, L., Teinila, K., Backman, J., Aurela, M., saarikoski, S., and Rönkko, T. (2018). Characteristics and Source Apportionment of Black Carbon in the Helsinki Metropolitan Area, Finland. Atmospheric Environment: 190 (January): 87-98. Auailable at 10.1016/j.atmosenu.2018.07.022 (Accessed 15 June 2020).

Herich, H., Gianini, M. F. D., Piot, C., Močnik, G., Jaffrezo, J.-L., Besombes, L., Preuot, A. S. H., and Hueglin, C. (2014). Overview of the Impact of Wood Burning Emissions on Carbonaceous Aerosols and PM in Large Parts of the Alpine Region. Atmospheric Environment: 89: 64-75. Auailable at 10.1016/j.atmosenu.2014.02.008 (Accessed 15 June 2020).

Ježek, I, Blond, N., Skupinski, G., and Močnik, G. (2018). The traffic emission-dispersion model for a Central-European city agrees with measured black carbon apportioned to traffic. Atmospheric Environment: 184: 177-190.

Kämtz, F. L. (1860). Über die Anleitung mittlerer Resultate aus meteorologischen Beobachtungen (On the calculation of mean results from meteorological observations). Repertitorium für Meteorologie: 1: 107-134.

Klimont, Z., Kupiainen, K., Heyes, C., Purohit, P., Cofala, J., Rafaj, P., Borken-Kleefeld, J., and Schöpp, W. (2017). Global anthropogenic emissions of particulate matter including black carbon. Atmospheric Chemistry and Physics: 17: 8681-8723.

Küpper, M., Quass, U., John, A. C., Kaminski, H., Leinert, S., Breuer, L., Gladtke, D., Weber, S., and Kuhlbusch, T. A. J. (2018). Contributions of Carbonaceous Particles from Fossil Emissions and Biomass Burning to PM 10 in the Ruhr Area, Germany. Atmospheric Environment: 189: 174-186. Auailable at 10.1016/j.atmosenu.2018.06.039 (Accessed 15 June 2020).

Mauklen, A., Alikhan, M., Akhmetkal, M. 2014. Assessing the level of environmental health security affected by atmosphere pollution. European Journal of Geography, 7(2): 72-84 
Manigrasso, M., Cosatabile, F., Alas, H., Aufderheide, M., Auino, P., Amato, F., Argentini, S., Barnaba, F., Berico, M., Bernardoni, V., Biondi, R., Casasanta, G., Ciampichetti, S., Calzolai, G., Canepari, S., Conidi, A., Coridell, E., Di Ianni, A., Di Liberto, L., Facchini, M. C., Facci, A., Frasca, D., Gilardoni, S., Grollino, M., G, Gualtieri, M., Lucarelli, F., Malaguti, A., Montagnoli, M., Nava, S., Perrino, C., Padoan, E., Petenko, I., Querol, X., Simonetti, G., Tranfo, G., Ubertini, S., Valli, G., Valentini, S., Vecchi, R., Volpi, F., Weinhold, K., Wiedensholer, A., Zanini, G., Gobbi, G. P., and Petralia, E. (2017). First Results of the 'Carbonaceous Aerosol in Rome and Enuirons (CARE)' Experiment: Beyond Current Standards for PM10. Atmosphere: 8(12): 41. Auailable at 10.3390/atmos8120249 (Accessed 15 June 2020).

Moosmüller, H., Chakrabarty, R. K., Ehlers, K. M., and Arnott, W. P. (2011). Absorption Ångström coefficient, brown carbon, and aerosols. Basic concepts, bulk matter, and spherical particles. Atmospheric Chemistry and Physics: 11: 1217-1225.

Ogrin, M, Vintar Mally, K., Planinšek, A., Gregorič, A., Močnik, G., and Drinovec, L. (2016). Nitrogen Dioxide and Black Carbon Concentrations in Ljubljana. GeograFF 18. Ljubljana: University Press, Faculty of Arts.

Ogrin, M. (2003). Vpliu reliefa na oblikouanje nekaterih mezoklimatskih tipou $v$ Sloveniji. Geografski vestnik: 75(1): 9-24.

Pachauri, R.K., and Meyer, L.A. (eds.). (2014). Climate Change 2014: Synthesis Report. Contribution of Working Groups I, II and III to the Fifth Assessment Report of the Intergovernmental Panel on Climate Change. Geneva: IPCC.

Petzold, A., Ogren, J. A., Fiebig, M., Laj, P., Li, S. M., Baltensperger, U., Holzer-Popp, T., Kinne, S., Pappalardo, G., Sugimoto, N., Wehrli, C., Wiedensohler, A., and Zhang, X. Y. (2013). Recommendations for reporting "black carbon" measurements. Atmospheric Chemistry and Physics: 13: 8365-8379. Auailable at 10.5194/acp-138365-2013 (Accessed 15 June 2020).

Rakovec, J., and Žabkar, R. (2012). Vpliui naraunih meteoroloških pogojeu na onesnaženost zraka. Zrak v Sloveniji, ed. Majkovič, D., Volfand, J, 95-103. Celje: Fit media.

Saleh, R., Hennigan, C. J., McMeeking, G. R., Chuang, W. K., Robinson, E. S., Coe, H., Donahue, N. M., and Robinson, A. L. (2013). Absorptivity of brown carbon in fresh and photo-chemically aged biomass-burning emissions. Atmospheric Chemistry and Physics: 13: 7683-7693. Auailable at 10.5194/acp-13-7683-2013 (Accessed 15 June 2020).

Sandradewi, J., Préuôt, A. S. H., Szidat, S., Perron, N., Alfarra, M. R., Lanz, V. A., Weingartner, E., and Baltensperger, U. (2008a.) Using aerosol light absorption measurements for the quantitative determination of woodburning and traffic emission contributions to particulate matter. Environmental Science \& Technology: 42: 3316-3323.

Sandradewi, J., Préuôt, A. S. H., Weingartner, E., Schmidhauser, R., Gysel, M., and Baltensperger, U. (2008b). A study of woodburning and traffic aerosols in an Alpine valley using a multi-wavelength Aethalometer. Atmospheric Environment: 42: 101112.

Wang, L., Stanič, S., Bergant, K., Eichinger, W., Močnik, G., Drinovec, L.,Vaupotič, J., Miller, M., Gosar, M., and Gregorič, A. (2019). Retrieual of Vertical Mass 
Concentration Distributions-Vipaua Valley Case Study. Remote Sensing: 11(2): 106. Auailable at 10.3390/rs11020106 (Accessed 15 June 2020).

Wählin, P., Olesen, H.R., Bossi, R., and Stubkjæer, J. (2010). Air pollution from residential wood combustion in a Danish village. Measuring campaign and analysis of results. 49 pp. National Enuironmental Research Institute. Denamark: Aarhus University. Auailable at 10.5194/acp-13-8365-2013 (Accessed 11 June 2020).

Zotter, P., Herich, H., Gysel, M., El-Haddad, I., Zhang, Y., Močnik, G., Hüglin, C., Baltensperger, U., Szidat, S., and Préuôt, A. S. H. (2017). Eualuation of the absorption Ångström exponents for traffic and woodburning in the Aethalometerbased source apportionment using radiocarbon measurements of ambient aerosol. Atmospheric Chemistry and Physics: 17: 4229-4249. Auailable at 10.5194/acp-174229-2017 (Accessed 11 June 2020). 